\title{
Emergency repair of the aortic arch in a premature newborn
}

\author{
Ireneusz Haponiuk ${ }^{1}$, Maciej Chojnicki ${ }^{1}$, Radoslaw Jaworski ${ }^{1}$, Ewelina Kwasniak ${ }^{1}$, Jacek Juscinski ${ }^{1}$, \\ Mariusz Steffens ${ }^{1}$, Aneta Szofer-Sendrowska ${ }^{1}$, Iwona Domzalska-Popadiuk ${ }^{2}$, \\ Katarzyna Gierat-Haponiuk ${ }^{3}$, Jacek Zielinski ${ }^{4}$
}

${ }^{1}$ Department of Pediatric Cardiac Surgery, Mikołaj Kopernik Pomeranian Centre of Traumatology, Gdansk 2Department of Neonatology, Medical University of Gdansk, Gdansk ${ }^{3}$ Department of Rehabilitation, Medical University of Gdansk, Gdansk ${ }^{4}$ Department of Surgical Oncology, Medical University of Gdansk, Gdansk

Kardiochirurgia i Torakochirurgia Polska 2013; 10 (2): 168-170

\begin{abstract}
We present a case of a successful two-step surgical treatment of a low body weight premature newborn (weight of $1140 \mathrm{~g}$ ) who underwent emergency surgical repair of aortic coarctation and closure of ventricular and atrial septal defects at the age of 7 months. In the end, the multi-staged strategy comprising the emergency repair of the coarctation and the subsequent intracardiac correction in the premature newborn turned out to be safe and effective. This may serve as encouragement to employ similar promising treatment methods for borderline low body mass newborns in the future.

Key words: aortic coarctation, aortic arch hypoplasia, prematurity, congenital heart defects, pediatric cardiac surgery.
\end{abstract}

\section{Introduction}

Critical coarctation of the aorta (CoA) is a duct-dependent congenital heart defect found in newborns, which necessitates surgical treatment immediately after diagnosis. Aortic coarctation usually coexists with other forms of aortic arch hypoplasia, as well as with intracardiac defects, the most common of which are ventricular septal defect and bicuspid aortic valve. The coexistence of aortic coarctation, mitral valve stenosis and subvalvular aortic stenosis is called Shone's syndrome [1, 2]. Contemporary therapy of choice is a surgical intervention aimed at augmenting the aortic arch, repairing the coarctation, and correcting other intracardiac anomalies during a single procedure [1]. The patients referred for surgery are usually critically ill newborns, with blood supplied to the lower parts of the body through patent ductus arteriosus (PDA) main-

\section{Streszczenie}

W artykule opisano dwuetapowe leczenie kardiochirurgiczne przedwcześnie urodzonego noworodka o masie ciała 1140 g, u którego rozpoznano koarktację aorty i ubytek w przegrodzie międzykomorowej oraz ubytek w przegrodzie międzyprzedsionkowej. W 11. dobie życia dziecka wykonano plastykę koarktacji aorty ze wskazań życiowych, a następnie w wieku 7 miesięcy zamknięto ubytek $w$ przegrodzie międzykomorowej i ubytek w przegrodzie międzyprzedsionkowej. Przyjęta strategia leczenia etapowego u opisywanego dziecka była bezpieczna oraz skuteczna i może w przyszłości znaleźć zastosowanie w leczeniu wcześniaków z wrodzonymi wadami serca i graniczne niską urodzeniową masą ciała.

Słowa kluczowe: koarktacja aorty, hipoplazja łuku aorty, wcześniactwo, wrodzone wady serca, kardiochirurgia dziecięca.

tained by intravenous prostaglandin E1 (PGE1). There is clear evidence that the extent of aortic arch hypoplasia, low body weight, and the prematurity of the referred newborns are independent risk factors for surgical treatment and increase the likelihood of future local restenosis [2].

There are several alternative strategies of care for premature low body weight infants with aortic coarctation. The most common method is based on prolonged PGE1 treatment to enable the infant's growth, while surgical intervention is postponed [3]. There are, however, reports of percutaneous and hybrid interventions in borderline infants.

We present a case of successful two-step surgical treatment of a low body weight premature newborn who underwent emergency surgical repair of aortic coarctation with a weight of $1140 \mathrm{~g}$ as well as the closure of ventricular and atrial septal defects at the age of 7 months.

Address for correspondence: Ireneusz Haponiuk MD, Department of Pediatric Cardiac Surgery, Mikołaj Kopernik Pomeranian Centre of Traumatology, 1-6 Nowe Ogrody Street, 80-803 Gdańsk, tel. +48 5832208 51, e-mail: ireneusz_haponiuk@poczta.onet.pl 


\section{Case study}

A male premature newborn (body weight of $1140 \mathrm{~g}$, born after 28 weeks of gestation) was admitted to the Department of Pediatric Cardiac Surgery in Gdańsk (Poland) on the $11^{\text {th }}$ day of life. The initial diagnosis was critical aortic coarctation (COA) and ventricular septal and secundum atrial septal defects (VSD + ASD II). The infant suffered from grade I/II intracranial hemorrhage and bronchopulmonary dysplasia, and was mechanically ventilated from birth. Continuous prostaglandin E1 (Prostin) infusion was administered at the Department of Neonatology in Gdańsk. Precise preoperative echocardiography showed a perimembranous VSD, a secundum atrial septal defect with unrestricted left-to-right shunts, a bicuspid aortic valve without any symptoms of dysfunction, and critical aortic coarctation. The distal part of the aortic arch was hypoplastic (below $1 / 3$ of the diameter of the ascending aorta) with typically localized $1.5 \mathrm{~mm}$ stenosis of the isthmus, without patent arterial duct (Fig. 1). The infant was ventilated during the admission. Despite abdominal distortion and clinical suspicion of imminent necrotizing enterocolitis (NEC), the critical laboratory test results were borderline normal.

The infant was referred for emergency surgical coarctation repair, although there were some doubts as to the possibility of transient mesenteric ischemia and abdominal deterioration. Finally, the procedure of coarctation repair with extended end-to-end anastomosis was performed on the $11^{\text {th }}$ day of life with complete cross-clamping of the aorta in normothermia using left posterolateral thoracotomy access; the postoperative course was uneventful. The ductal tissue was resected with a macroscopically confirmed margin of normal aortic wall [4].

During the interstage period, the patient received comprehensive therapy for respiratory disturbances resulting from bronchopulmonary dysplasia, presenting as dyspnea at rest, mild cyanosis and mild hypercapnia. The blood flow through the VSD was left-to-right, exhibiting an echocardiographic pattern characteristic of left atrial and left ventricle enlargement. The echocardiographic assessment of pulmonary artery pressure indicated elevated pressure with dynamic inflow to the left atrium, as well as left atrial enlargement.

Finally, the child underwent a successful procedure of closing the ventricular and atrial septal defects with early childhood caries (ECC) at the age of 6 months, when he reached the body weight of $4 \mathrm{~kg}$. Despite the bronchopulmonary dysplasia observed on a chest X-ray (Fig. 2), the postoperative period was uneventful.

\section{Discussion}

The premature infant with critical coarctation was referred for emergency surgery despite low weight and
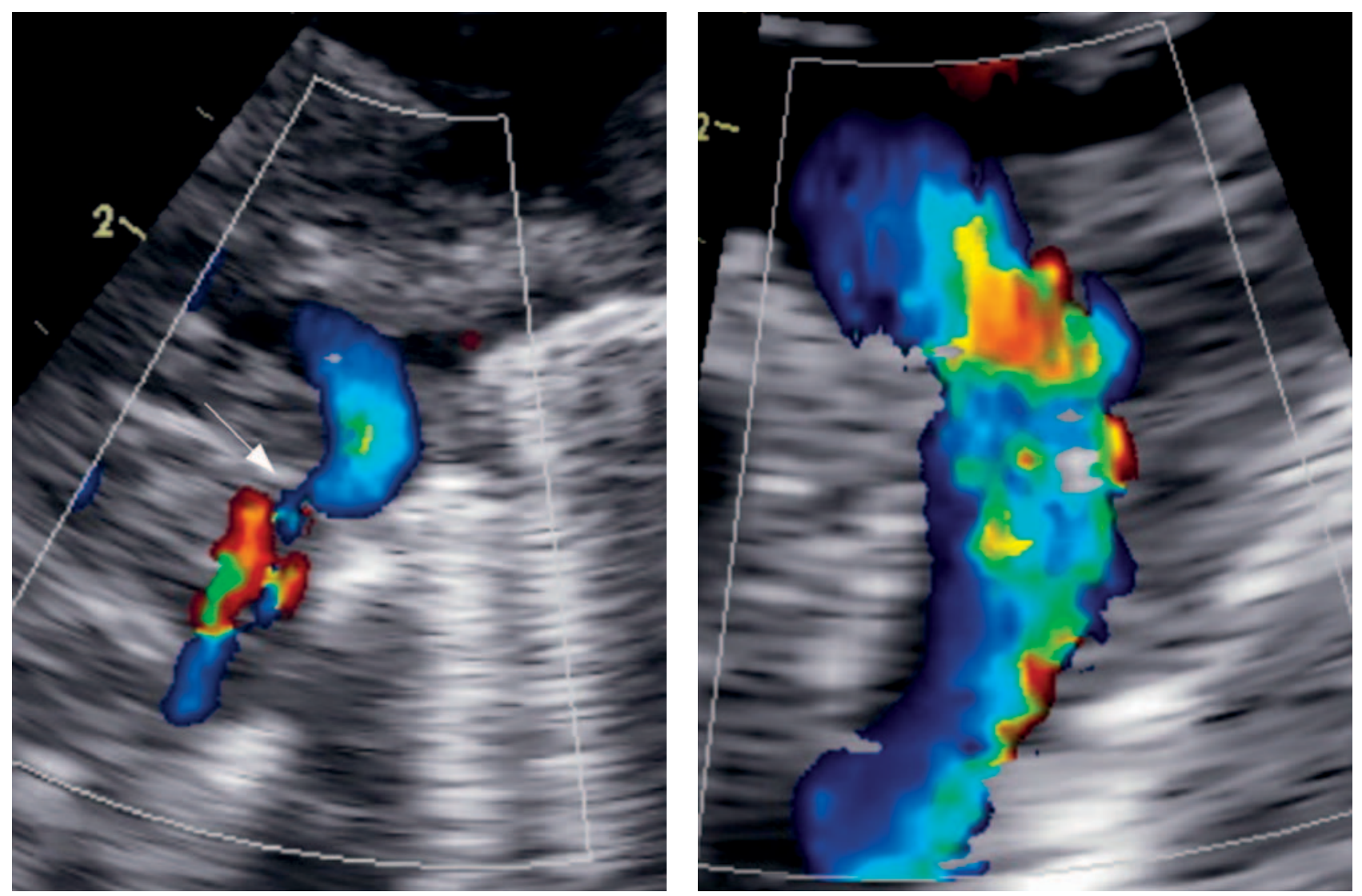

Fig. 1. Echocardiography - suprasternal color Doppler image of the patient showing the coarctation of the aorta (arrow): preoperative (A) and postoperative (B) view 


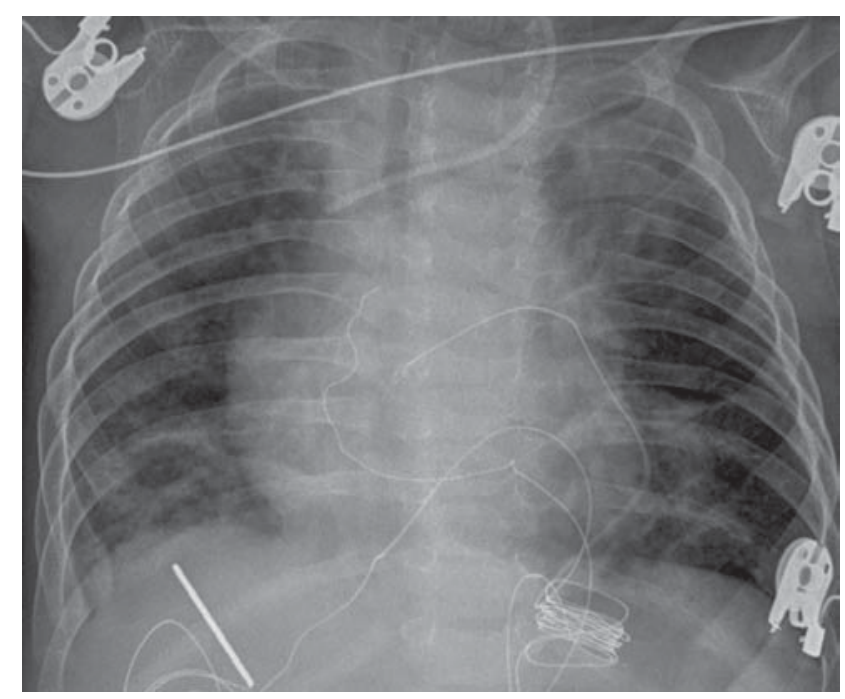

Fig. 2. Postoperative chest $X$-ray showing the symptoms of diffuse bronchopulmonary dysplasia

the risk of additional complications resulting from prematurity. The decision to perform a surgical intervention was the only possibility in the case an infant who weighed 1 kilogram and did not meet the criteria for percutaneous balloon plasty or stent implantation [2]. It is not uncommon for borderline patients who are treated pharmacologically and have no real option of surgery to deteriorate despite the use of maximal conventional therapies. Following the few available reports, we decided to operate on the infant in spite of the increased risk resulting from the extremely low body weight $[5,6]$.

Different operative methods are used for ductal tissue resection with aortic arch anastomosis. The common elements include posterolateral left-sided thoracotomy access, complete aortic cross-clamping, and, in the majority of cases, normothermia [2]. Extended end-to-end anastomosis, the most popular of these methods, was the technique of choice, which enabled the repair of the coarctation and the subsequent augmentation of the aortic arch.

The two-stage strategy to repair the coarctation, without PA banding during the first stage, appeared safe and effective. The intracardiac repair by means of cardiopulmonary bypass was postponed until after the infant reached a more optimal body mass and appropriate 'corrected' age. The patient underwent regular interstage examinations in the department in order to coordinate optimal therapy plans.

In the presented case, the two-step strategy was undertaken because of the prematurity and low body weight of the infant, as well as the coexistence of critical aortic coarctation and aortic arch hypoplasia, which necessitated the surgical repair of the arch. The intention was to avoid the potential adverse effects of peripheral vascular access used for palliative balloon plasty or stent implantation. The strategy based on prolonged prostaglandin therapy was inadvisable because of the mentioned early PDA closure which did not respond to pharmacological treatment.

\section{Conclusions}

Ultimately, the multi-staged strategy comprising the emergency repair of the coarctation and the subsequent intracardiac correction in the premature newborn turned out to be safe and effective. This may serve as encouragement to employ similar promising treatment methods for borderline low body mass newborns in the future. Percutaneous or hybrid strategies were deliberately abandoned despite the fact that the authors had had positive personal experience with these methods, because the associated risk of complications related to peripheral vessels and surgical access in a low body weight newborn seemed too high.

\section{References}

1. Kenny D, Hijazi ZM. Coarctation of the aorta: From fetal life to adulthood. Cardiology J 2011; 16: 487-495.

2. Haponiuk I, Skalski J. Koarktacja aorty. In: Kardiochirurgia dziecięca. Skalski J, Religa Z (eds.). Wydawnictwo Naukowe Śląsk, Katowice 2000.

3. Sudarshan CD, Cochrane AD, Jun ZH, Soto R, Brizard CP. Repair of coarctation of the aorta in infants weighing less than 2 kilograms. Ann Thorac Surg 2006; 82: 158-163.

4. Jonas RA. Coarctation: do we need to resect ductal tissue? Ann Thorac Surg 1991; 52: 604-607.

5. Croti UA, Braile DM, Yamamoto AE, Kozak AC. Correction of aortic coarctation using end anastomosis in premature newborn. Rev Bras Cir Cardiovasc 2010; 25: 594-595.

6. Kazmierczak P, Moll JA, Moll JJ. CoA low body weight 1200 g. Kardiochir Torakochir Pol 2010; 7: 27-29. 